\title{
The effect of supplementation of grass silage with rapeseed meal or Gasol-treated barley on the performance of growing cattle
}

\author{
PEKKA HUHTANEN, ESKO POUTIAINEN ${ }^{1}$ and TIMO MIKKOLA ${ }^{2}$ \\ Department of Animal Husbandry, University of Helsinki, \\ SF-00710 Helsinki
}

\begin{abstract}
Grass silage was offered ad libitum to 16 Ayrshire cattle in a $2 \times 2$ factorial experiment lasting 196 days. The silage was supplemented with barley preserved with $0.85 \%$ of propionic acid (PAB) or $1.28 \%$ Gasol solution (GB) $45 \mathrm{~g} \mathrm{DM} / \mathrm{kg} \mathrm{W}^{0.75}$. Four of the animals in PAB and GB groups received no protein supplement (NPS) and four of the animals in both groups received extracted rapeseed meal as protein supplement (RSM). RSM was fed according to UDP (undegradable feed protein) requirements. The average age of the animals at the beginning of the experiment was 86 days and the average liveweight $106 \mathrm{~kg}$.

The average daily gains were 1066 and $1070 \mathrm{~g} / \mathrm{d}$ for PAB and GB groups and 1012 and $1124 \mathrm{~g} / \mathrm{d}(\mathrm{P}<0.01)$ for NPS and RSM groups. In feed intake and feed conversion there were no significant differences between the groups. Supplementation of silage barley diet with RSM increased the digestibility of organic matter from 71.1 to $73.5 \%$ ( $\mathrm{P}<0.05$ ), of crude protein from 62.8 to $67.4 \%(\mathrm{P}<0.05)$ and of crude fibre from 57.2 to $60.2 \%$ ( $\mathrm{P}<0.05$ ).

Both barleys were well preserved and there was no deterioration during the storage. The degradation rates of DM, crude protein and starch determined by nylon bag method were lower in GB than in PAB. Crude protein disappearances in 9 hours were $46.6 \%$ for GB and $76.4 \%$ for PAB.

The utilization of absorbed protein calculated by factorial method averaged $0.566 \pm 0.01$ in the four different groups.

Plasma urea $\mathrm{N}$ level was higher $(\mathrm{P}<0.05)$ in the RSM than in the NPS group. The proportion of acetic acid in the rumen VFA was lower $(\mathrm{P}<0.05)$ and that of propionic acid higher $(\mathrm{P}<0.01)$ in the RSM than in the NPS group. PAB resulted in a higher $(\mathrm{P}<0.05)$ proportion of propionic acid in rumen VFA than did GB.
\end{abstract}

\section{Introduction}

New protein evaluation systems recognize that the amino acids available to ruminants will be supplied partly by microbial protein synthesis in the rumen and partly from dietary protein, that is undegradable in the rumen. According to the ARC system (ANON 1980), growing cattle of more than $250 \mathrm{~kg}$

1 Present adress:

Agricultural Research Centre,

SF-31600 Jokioinen.

2 Farmos Group, Agricultural Division, Tengströminkatu 6. SF-20360 Turku.

Index words: rapeseed meal, protected barley, protein utilization, growing cattle 
can meet their protein requirements from microbial synthesis. More recent information (ØRSKOv and McLEOD 1982) suggests that endogenous $\mathrm{N}$ losses may be greater than previously thought and protein reguirements may need to be revised upwards.

The crude protein of grass silage is rapidly degraded in the rumen, especially when the NPN content of the silage is high (SETÄLÄ $1983 \mathrm{a}$ ), and the supplementation with undegradable protein may therefore be advantageous for animals with high protein requirements. In many experiments supplementation of grass silage with fish meal (FM) (Garstang et al. 1979, Kirby and Chalmers 1982, KIrBy et al. 1983 a, KAY and SCOTT 1984 ) or with soyabean meal SBM (KIRBY et al. 1983 b, WATERHOUSE et al. 1983) has increased the liveweight gain of growing cattle. The responses to liveweight gain are partly due to increased silage DM intake and partly to an increase in undegraded feed protein. Values for efficiency of microbial protein synthesis in animals given silage diets are lower than in animals given hay (THомAS 1982). In addition the proportion of methionine of total amino acids in duodenal digesta is lower on silage than on hay diets (Thomas 1982). Methionine is frequently the first limiting amino acid in ruminants.

In Finland beef cattle feeding is often based on silage ad libitum and $2-4 \mathrm{~kg}$ of barley/d. Protein supplements are seldom used in grass silage based feeding. On such a diet the amount of UDP is very low and the protein flow into the duodenum depends mainly on microbial protein synthesis. One possible method to increase dietary protein flow into the duodenum is to protect it against microbial degradation in the rumen. According to a review by KAUFMANN and LÜPPING (1982), protected protein tends to improve weight gain and feed conversion.

The present experiment was designed to evaluate the effect of rapeseed meal, the most important protein supplement produced in Finland, and Gasol-treated barley as
UDP sources for growing cattle on silage based diet.

\section{Material and methods}

Animals and feeding

A feeding trial of $2 \times 2$ factorial design was carried out with 12 bulls and 4 heifers of Finnish Ayrshire breed. The animals were taken in four blocks into the experiment, at the average weight of $106 \mathrm{~kg}$ and average age of $86 \mathrm{~d}$. The animals were divided into four similar groups with respect to sex, age and liveweight. The four treatments consisted of two barleys, each either supplemented with rapeseed meal (RSM) or given without supplements (NPS). The barleys were preserved at a moisture content of $20-22 \%$ with addition of $0.85 \%$ of propionic acid (PAB) or $1.28 \%$ of Gasol solution (GB), which is a mixture of organic acids and formalin. The experiment lasted 196 days after which the bulls were slaughtered. The animals were weighed at the beginning and end of the experiment on two consecutive days and during the experiment every second week.

Unwilted grass silage, preserved with AIV II solution ( $80 \%$ formic acid, $2 \%$ orthophosphoric acid), was offered ad libitum in quantities that were 5-10 \% in excess of the previous day's consumption. In addition to the silage, $45 \mathrm{~g} \mathrm{DM} / \mathrm{kg} \mathrm{W}^{0.75}$ of rolled barley was offered. In the RSM group the animals received extracted RSM according to calculated UDP requirements (ARC, ANON 1980). If there was no calculated UDP requirement the amount of RSM was then $0.2 \mathrm{~kg} / \mathrm{d}$. A commercial mineral mixture was provided to the amount of $100 \mathrm{~g} / \mathrm{d}$ and a vitamin mixture every week according to the requirements. Barley, RSM and mineral mixture were mixed prior to feeding. The animals were fed individually twice daily. Feed refusals were weighed every day.

Sampling and analyses

The feeds were sampled once a week and 
pooled into one sample for two weeks for silage and barleys and into one sample for four weeks for RSM. DM determination was made of every sample and feed analyses of pooled samples. DM content was determined at $103^{\circ} \mathrm{C}$ and samples for feed analyses were dried in vacuum at $50^{\circ} \mathrm{C}$. DM content of silage was corrected and $\mathrm{pH}$, lactic acid, sugars, ammonia $\mathrm{N}$ and VFA were analyzed as described by Huhtanen (1984 a). Feed analyses were made according to standard methods.

Degradabilities in the rumen of crude protein and DM of all experimental feeds and of starch of barleys were determined by nylon bag method (SETÄLÄ 1983 b). The feeds were incubated in the rumen of sheep receiving the same feeds in the same proportion as the animals in the feeding trial. The feeds for in sacco determinations were pooled into one sample for four weeks. The starch content of barleys and nylon bag residues was determined by the method of SALO and SALMI (1968).

Rumen samples were taken from the bulls 10 weeks after the start of the experiment with a $2 \times 60 \mathrm{~mm}$ needle through the rumen wall before, and 2.5 and 5 hours after the morning feeding. $\mathrm{pH}$ was measured immediately; ammonia $\mathrm{N}$ was measured by the method of McGullough (1967) and VFA from deep frozen supernatant by the method of Huida (1973). Blood samples were taken from Vena jugularis at the beginning of the experiment and every eight weeks thereafter before the morning feeding. The samples were treated and analyzed as described by HuHTANEN (1984 b).

In vivo digestibility of the rations was determined by indicator method with chromic oxide as marker. Five grams of chromic oxide paper was fed directly into the oesophagus twice daily for 12 days. Grab samples of faeces were obtained from the rectum during the last five days, twice daily. Faeces were dried and analyzed by standard methods as feed samples. Chromic oxide was determined by the method of PETRY and RAPP (1971).

\section{Calculations}

Rumen degradable protein (RDP), UDP and organic matter fermented in the rumen (OMF) were calculated using degradabilities obtained from nylon bag studies. OMF determined by nylon bag method was assumed to be the true digestibility in the rumen. Apparently fermented organic matter in the rumen $\left(\mathrm{OMF}_{\mathrm{A}}\right)$ was calculated assuming a value of $20 \mathrm{~g} \mathrm{~N} / \mathrm{kg}$ truly digested $\mathrm{OM}$ for the efficiency of microbial synthesis in the rumen and assuming the $\mathrm{N}$ content of microbial $\mathrm{OM}$ to be $10 \%$. The UDP requirement was calculated according to ARC (ANON 1980). The efficiency of microbial synthesis has been shown to be lower on silage diets than on hay diets (Armstrong 1980, Thomas 1982). The value used for the efficiency of microbial synthesis was $25 \mathrm{~g} \mathrm{~N} / \mathrm{kg} \mathrm{OMF}_{\mathrm{A}}$ proposed by THOMAS and CHAMBERLAIN (1982) for silage diets, which is $5 \mathrm{~g}$ lower than proposed in the ARC system for all diets.

The differences between the groups were tested with three-way analyses of variance with interaction between the type of barley and protein level (STEEL and TORrie 1960).

\section{Results and discussion}

Feed composition, feed intake and liveweight gain

The mean chemical composition, calculated energy and DCP values and degradabilities are given in Table 1. There were large differences in nutritional value of the silage (OM in vitro digestibility 60.4-71.6\%) and in quality of the silage (ammonia 3.6-13.3 \% of total N). The barleys were well preserved and the additives caused no differences in the quality. The proportion of water soluble $\mathrm{N}$ of total $\mathrm{N}$ was higher in PAB than GB (16.9 vs. 7.4). GB had a clearly slower degradation rate of crude protein in the rumen, and also the degradation rate of DM and starch were slightly slower (Fig. 1). 
Table 1. Chemical composition and feeding values of experimental feeds.

\begin{tabular}{lcccc}
\hline & $\begin{array}{c}\text { Grass } \\
\text { silage }\end{array}$ & $\begin{array}{c}\text { Propionic-acid } \\
\text { treated barley }\end{array}$ & $\begin{array}{c}\text { Gasol treated } \\
\text { barley }\end{array}$ & $\begin{array}{c}\text { Rapeseed } \\
\text { meal }\end{array}$ \\
\hline $\begin{array}{l}\text { Dry matter, \% } \\
\text { In dry matter, \% }\end{array}$ & 22.5 & 81.3 & 79.3 & 88.8 \\
$\quad$ Ash & 7.4 & 3.1 & 3.0 & 8.1 \\
Crude protein & 16.3 & 12.9 & 12.4 & 37.9 \\
Ether extract & 6.0 & 2.4 & 2.4 & 2.6 \\
Crude fibre & 33.2 & 6.6 & 7.0 & 14.2 \\
NFE & 37.1 & 75.0 & 1.08 & 37.3 \\
FU/kg DM & 0.69 & 1.08 & 87 & 0.91 \\
DCP g/kg DM & 107 & 90 & 12.6 & 314 \\
ME MJ/kg DM & 9.8 & 12.6 & 67.2 & 11.0 \\
Degradability, \% & & & 47.2 & 45.3 \\
Organic matter & 58.1 & 77.3 & 77.5 & 54.9 \\
Crude protein & 84.4 & & & \\
\hline
\end{tabular}

FU = feed unit. " $\mathrm{pH} 3.97$, lactic acid $5.7 \%$, sugars $5.5 \%$, acetic acid $1.9 \%$, propionic acid $0.1 \%$, butyric acid $0.2 \%$ of DM, ammonia N $6.6 \%$ of total N.

Table 2. The average feed intake ( $\mathrm{kg} \mathrm{DM} / \mathrm{d})$ and nutrient consumption.

\begin{tabular}{|c|c|c|c|c|c|}
\hline & \multicolumn{2}{|c|}{ Barley } & \multicolumn{2}{|c|}{ Protein } & \multirow{2}{*}{ SEM } \\
\hline & PAB & GB & NPS & RSM & \\
\hline Grass silage & 2.29 & 2.44 & 2.40 & 2.34 & 0.07 \\
\hline Barley & 2.14 & 1.98 & 1.97 & 2.15 & 0.11 \\
\hline Rapeseed meal & 0.12 & 0.09 & - & 0.21 & 0.01 \\
\hline Total DM & 4.55 & 4.51 & 4.37 & 4.69 & 0.14 \\
\hline $\mathrm{DM} \mathrm{g} / \mathrm{kg} \mathrm{W}^{0.75}$ & 83.5 & 82.1 & 81.6 & 84.0 & 1.2 \\
\hline FU/d & 3.99 & 3.90 & 3.78 & 4.11 & 0.13 \\
\hline $\mathrm{ME} \mathrm{MJ/d}$ & 50.8 & 49.9 & 48.4 & 52.4 & 1.6 \\
\hline DCP g/d & 486 & 474 & $442^{c}$ & $518^{\mathrm{d}}$ & 13 \\
\hline
\end{tabular}

Means with different letters significantly different: $c, d(P<0.01)$.

Feed intake and nutrient consumption data are given in Table 2. RSM had no effect on silage DM intake, which is in dis-

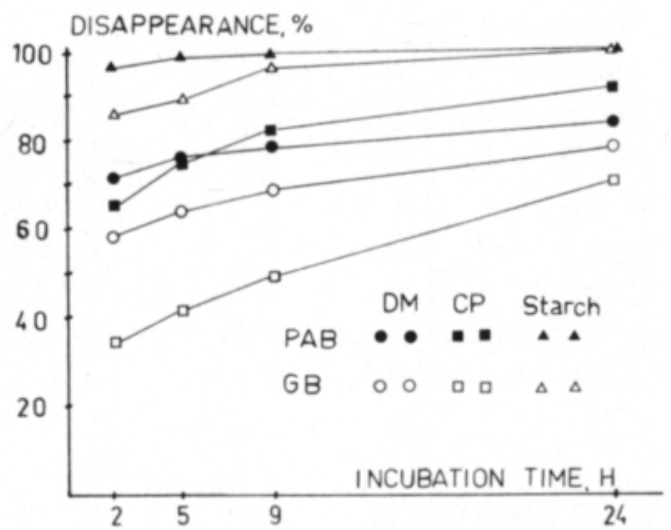

Fig. 1. The effect of Gasol treatment on degradation rate of barley DM, crude protein and starch. agreement with the results obtained with other protein supplements, e.g. with SBM (WAterhouse et al. 1983, Kirby et al. 1983 b), with FM (KAY and KING 1984, KIRBY et al. 1983 a, 1983 b, Gill and ENGLAND 1983) and with groundnut meal (Gill and ENGLAND 1984). Chalmers et al. (1983) did not find any differences between FM and SBM in the effect on silage DM intake. The response to supplementary protein may depend on the fermentation quality of the silage. Thомаs et al. (1980) observed that the intake with FM supplement increased more when the lactic acid content of the silage was higher. In the present study the following correlations between the silage parameters and silage DM intake $/ \mathrm{kg} \mathrm{W}^{0.75}$ were obtained: DM content 0.224 ( $\mathrm{P}<0.01)$, crude protein 0.388 
Table 3. Animal performance and carcass data.

\begin{tabular}{lcccccc}
\hline & \multicolumn{2}{c}{ Barley } & & \multicolumn{2}{c}{ Protein } & SEM \\
\cline { 2 - 3 } \cline { 5 - 6 } & PAB & GB & & NPS & RSM \\
\hline Number of animals & 8 & 8 & & 8 & 8 & \\
Initial weight, kg & 105.1 & 107.0 & & 106.4 & 105.8 & 4.3 \\
Final weight, kg & 314.1 & 316.8 & & 304.8 & 326.1 & 9.3 \\
Daily gain, kg/d & 1.066 & 1.070 & & $1.012^{c}$ & $1.124^{d}$ & 0.025 \\
Feed conversion, FU/kg gain & 3.77 & 3.64 & & 3.75 & 3.66 & 0.13 \\
Slaughter weight1), kg & 326.5 & 330.3 & & 322.8 & 334.0 & 9.5 \\
Carcass weight, kg & 163.7 & 162.8 & & 158.2 & 168.3 & 5.2 \\
Dressing \% & 50.1 & 49.3 & & 49.0 & 50.5 & 0.7 \\
\hline
\end{tabular}

1) Only bulls were slaughtered. Means with different letters significantly different $\mathrm{c}, \mathrm{d}(\mathrm{P}<0.01)$

( $\mathrm{P}<0.001), \quad$ crude fibre -0.463 $(\mathrm{P}<0.001), \mathrm{OM}$ in vitro digestibility 0.354 $(\mathrm{P}<0.001)$, sugars $0.306(\mathrm{P}<0.001)$, lactic acid $-0.030(\mathrm{NS})$, butyric acid -0.295 $(\mathrm{P}<0.001)$, ammonia $\mathrm{N} \%$ of total $\mathrm{N}$ $-0.359(\mathrm{P}<0.001)$ and soluble $\mathrm{N} \%$ of total N 0.038 (NS).

RSM supplementation increased significantly $(\mathrm{P}<0.01)$ the liveweight gain of the animals (Table 3). The difference in daily gain between NPS and RSM was higher in the first part of the experiment $(0.95 \mathrm{~kg}$ vs. $1.10 \mathrm{~kg}$ on days $1-98$ and $1.08 \mathrm{vs} .1 .14 \mathrm{~kg}$ on days 99-196), suggesting that at that time the amino acid flow into the duodenum was the growth limiting factor. Finnish DCP requirements (SALO et al. 1982) were not met in the NPS group during the first month of the experiment. RSM had no significant effect on feed conversion rate. The effect of RSM on daily gain agrees with the effect of protein supplementation on silage based diets (Garstang et al. 1979, Kirby et al. 1983 a, 1983 b, WATERHOUSE et al. 1983, KAY and SCOTT 1984). The response to FM has often been higher than to SBM (KIRBY and Chalmers 1982, Kirby et al. 1983 a). Also on ad libitum concentrate feeding the response to FM has been better than to SBM, especially in younger bulls (LINDBERG and Olsson 1983). Olsson (1978) reported reduced performance in calves fed a ration containing $13 \%$ of high glucosinolate RSM compared with calves fed SBM, but for cattle between 80 and $240 \mathrm{~kg}$ liveweight there were no differences between RSM and SBM.

Protecting barley with Gasol had no effect on liveweight gain, which agrees with the results of EDWARDS et al. (1984) for barley treated in the same way. KAUfMANN and LÜPING (1982), on the other hand, found an average higher liveweight gain with protected protein than with untreated protein. The amino acid composition of barley protein, however, is poor compared with microbial protein or tissue protein. Alaviuhrola and NÄSI (1984) found lower lysine content in Gasol-treated barley than in dried barley. THORNTON et al. (1977) reported increasing nonammonia $\mathrm{N}$ flow into the duodenum with increasing formaldehyde content in ensiled corn, but $\mathrm{N}$ retention was not increased and $\mathrm{N}$ excretion in urine was increased with formaldehyde treatment. DAvIS and FAICHNEY (1973) reported lower liveweight gain with formaldehyde treated barley than in untreated barley. In the present study there was no interaction between protein supplement and barley treatment in feed intake, daily gain or feed conversion rate. In carcass characteristics there were no significant differences between the treatments. Dressing \% tended to be higher in the RSM than in the NPS group.

RSM supplementation significantly improved the digestibility of DM, OM, crude protein and crude fibre (Table 4). The same effect was found earlier for supplementary 


\begin{tabular}{lcccccc}
\hline & \multicolumn{2}{c}{ Barley } & & \multicolumn{2}{c}{ Protein } & \multirow{2}{*}{ SEM } \\
\cline { 2 - 3 } \cline { 5 - 6 } & PAB & GB & & NPS & RSM \\
\hline Dry matter & 71.0 & 69.7 & & $69.2^{\mathrm{a}}$ & $71.5^{\mathrm{b}}$ & 0.67 \\
Organic matter & 72.9 & 71.7 & & $71.1^{\mathrm{a}}$ & $73.5^{\mathrm{b}}$ & 0.64 \\
Crude protein & 66.6 & 63.6 & & $62.8^{\mathrm{a}}$ & $67.4^{\mathrm{b}}$ & 1.07 \\
Ether extract & 69.1 & 66.7 & & 66.4 & 69.4 & 0.98 \\
Crude fibre & 58.8 & 58.6 & & $57.2^{\mathrm{a}}$ & $60.2^{\mathrm{b}}$ & 0.95 \\
NFE & 79.1 & 78.0 & & 77.7 & 79.2 & 0.59 \\
\hline
\end{tabular}

Means with different letters were significantly different: $a, b(P<0.05)$

Table 5. Nitrogen utilization of the animals.

\begin{tabular}{lcccc}
\hline & \multicolumn{2}{c}{ Barley } & \multicolumn{2}{c}{ Protein } \\
\cline { 2 - 3 } & PAB & GB & NPS & RSM \\
\hline Crude protein, g/d & 707.0 & 692.8 & 653.0 & 746.3 \\
RDP, g/d & 563.5 & 482.6 & 497.5 & 548.2 \\
Microbial protein, g/d & 364.5 & 332.0 & 337.3 & 360.3 \\
UDP, g/d & 143.5 & 210.2 & 155.6 & 198.1 \\
Total, g/d & 508.0 & 542.2 & 492.9 & 558.4 \\
Absorbed protein, g/d & 355.6 & 379.5 & 345.0 & 390.9 \\
TP1)/absorbed protein & 0.585 & 0.548 & 0.581 & 0.551 \\
\hline
\end{tabular}

1) Tissue protein, calculated according to ARC (Anon. 1980)

FM (BAX and OFFer 1982, GILl and ENGLAND 1983). Gill and ENGLAND did not find significant differences between FM and more degradable groundnut meal in the effect on silage digestibility. The reason for the positive response to supplemental protein may be increased digestion in the rumen. LINDBERG (1984) found the digestibility of silage in the rumen determined by nylon bag method to increase from $54 \%$ to $64 \%$ when $2.6 \mathrm{~kg}$ barley DM was replaced with SBM in the diet of dairy cow. In silage the major proportion of the protein is degraded in the silo and this may result in a shortage of amino acids and/or peptides, which are believed to be important growth factors for rumen microbes. In the present study Gasol treatment tended to decrease the apparent digestibility of crude protein, which effect is often found when high levels of formaldehyde are used (KAUFMANN and LüPPING (1982).

Nitrogen utilization

At the beginning of the experiment the animals did not meet their UDP requirements because they did not eat all the feed given. Calculated utilization of absorbed protein for conversion into tissue protein was on average $0.566 \pm 0.010$ for different diets (Table 5), which is lower than proposed by ARC (ANon. 1980). SAtTer and Roffler (1975) and Verite et al. (1979) suggested the utilization of absorbed amino $\mathrm{N}$ for growth to be 0.60 . In the present study the calculated efficiency for protein utilization decreased with increasing liveweight. The following linear regression was calculated between protein utilization and liveweight:

$$
\begin{aligned}
& \mathrm{y}=1.060-0.0022 \mathrm{X}, \text { where } \\
& \mathrm{y}=\text { protein utilization and } \\
& \mathrm{x}=\text { liveweight }(\mathrm{kg})
\end{aligned}
$$

Low efficiency for protein utilization in the later part of the experiment suggests that absorbed amino acids were no longer a growth limiting factor and the effect of RSM after $230-250 \mathrm{~kg}$ of liveweight was based mainly on increased energy intake. On the other hand, KIRBY et al. (1983 a) reported 
Table 6. $\mathrm{pH}$, ammonia $\mathrm{N}$ and VFA in rumen fluid. The values are averages of different sampling times.

\begin{tabular}{|c|c|c|c|c|c|}
\hline & \multicolumn{2}{|c|}{ Barley } & \multicolumn{2}{|c|}{ Protein } & \multirow{2}{*}{ SEM } \\
\hline & РAB & GB & NPS & RSM & \\
\hline $\mathrm{pH}$ & 6.64 & 6.70 & 6.74 & 6.60 & 0.09 \\
\hline Ammonia $\mathrm{N}, \mathrm{mmol} / \mathrm{l}$ & 6.02 & 5.33 & 4.95 & 6.38 & 0.93 \\
\hline Total VFA, mmol/1 & 98.1 & 98.0 & 94.7 & 101.2 & 4.2 \\
\hline \multicolumn{6}{|l|}{ Molar per cent of } \\
\hline Acetic acid & 66.3 & 67.4 & $67.7^{a}$ & $66.0^{b}$ & 0.5 \\
\hline Propionic acid & $20.7^{\mathrm{a}}$ & $19.6^{b}$ & $19.4^{\mathrm{c}}$ & $20.9^{d}$ & 0.3 \\
\hline Butyric acid & 9.6 & 9.4 & 9.5 & 9.5 & 0.4 \\
\hline Isovaleric acid & 1.9 & 1.6 & 1.8 & 1.7 & 0.1 \\
\hline Valeric acid & 1.4 & 1.3 & 1.3 & 1.3 & 0.1 \\
\hline
\end{tabular}

Means with different letters were significantly different: a,b $(\mathrm{P}<0.05)$, c,d $(\mathrm{P}<0.01)$

increased liveweight gains with FM even at a liveweight of $500 \mathrm{~kg}$ and WATERHOUSE et al. (1983) with SBM at a liveweight of $320-$ $470 \mathrm{~kg}$. These effects cannot be explained by the ARC 1980 system.

One reason for lower protein utilization may be, in addition to low efficiency of microbial synthesis, the poorer amino acid composition in the duodenal digesta on silage than on hay diets (Тномаs and СнамBERLAIN 1982).

Following ARC (1980), the apparent absorption of amino acids used in the present calculation was 0.70 , which is higher than the 0.63 adjusted for silage diets proposed by Thomas and Chamberlain (1982). Of total DOM, the proportions of OM apparently fermented in the rumen DOM were 74.3, 69.5, 73.5 and $70.6 \%$ for diets PAB, GB, NPS and RSM, which are close to the value presented by ThOmas and Chamberlain (1982) for silage diets. They presented a more appropriate equation for microbial synthesis for silage diets, in which the amount of microbial $\mathrm{N}$ absorbed from small intestine and deposited in the tissues is $0.41 \mathrm{~g}$ $\mathrm{N} / \mathrm{MJ}$ ME. The corresponding value in the ARC 1980 system is 0.53 for all diets.

Efficiency of microbial synthesis in silage diets is lower, because silage OM consists of silage fermentation products and the yield of $\mathrm{ATP} / \mathrm{kg} \mathrm{OMF}$ A is lower (Thomas 1982). Another reason may be that the rates of ammonia and energy release from silage are poorly matched. However, GILL and ENGLAND (1983) got a much lower increase in daily gain with sucrose than with FM supplements in calves fed silage diet. Tномаs et al. (1980) did not observe any effect of barley supplement on the efficiency of microbial synthesis on formic acid silage diet. With protein supplements the efficiency of protein synthesis has sometimes increased (ARMSTRONG 1980).

Calculated RDP intake was much higher than requirement, which was also found by Setälä et al. (1984) in dairy cows fed a similar diet. Degradability of silage crude protein was $84 \%$, much higher than values reported for formic acid silage in duodenum cannulated animals (Тномаs et al. 1980, Tномson et al. 1981) and closer to values reported for non-additive silage (BEEver et al. 1977). In the present study, calculated amino $\mathrm{N}$ flow into the duodenum was much lower than $\mathrm{N}$ intake, indicating high ammonia losses from the rumen.

Rumen fermentation and blood composition

There were no significant differences in rumen $\mathrm{pH}$, total VFA or ammonia $\mathrm{N}$ concentration (Table 6). Ammonia $\mathrm{N}$ tended to be higher on RSM and PAB diets than on NPS and GB diets. Total VFA concentration was slightly higher on RSM than on NPS diet indicating more intensive fermentation of RSM diet. The differences in proportions of 
Table 7. The mean concentration of blood constituents during the experiment.

\begin{tabular}{|c|c|c|c|c|c|}
\hline & \multicolumn{2}{|c|}{ Barley } & \multicolumn{2}{|c|}{ Protein } & \multirow{2}{*}{ SEM } \\
\hline & PAB & GB & NPS & RSM & \\
\hline Glucose, mmol/1 & 5.42 & 5.22 & 5.37 & 5.27 & 0.08 \\
\hline Total protein, $\mathrm{g} / 1$ & 67.3 & 67.7 & 68.0 & 66.9 & 1.4 \\
\hline Albumin, $\mathrm{g} / 1$ & 37.2 & 36.7 & 37.0 & 36.9 & 0.5 \\
\hline Urea $\mathrm{N}, \mathrm{mmol} / 1$ & 2.23 & 1.94 & $1.86^{\mathrm{a}}$ & $2.32^{\mathrm{b}}$ & 0.12 \\
\hline Ammonia $\mathrm{N}, \mathrm{mg} / 100 \mathrm{ml}$ & 0.11 & 0.11 & 0.10 & 0.11 & 0.01 \\
\hline Creatinine, $\mathrm{mol} / 1$ & 95.4 & 93.9 & 90.3 & 99.0 & 5.2 \\
\hline AFOS', IU/I & 257 & 246 & 262 & 244 & 10.4 \\
\hline $\mathrm{ASAT}^{2)}, \mathrm{IU} / 1$ & 57.8 & 55.4 & 55.8 & 57.5 & 3.5 \\
\hline Cholesterol, mmol/1 & 2.47 & 2.53 & 2.45 & 2.55 & 0.11 \\
\hline
\end{tabular}

1) Alkaline phosphatase, ${ }^{2)}$ aspartate aminotransferase.

Means with different letters were significantly different: $a, b(P<0.05)$

VFA were small, although significant in the proportion of propionic acid.

RSM caused a significant $(\mathrm{P}<0.05)$ increase in plasma urea $\mathrm{N}$ (Table 7), which agrees with results for other protein supplements (KIRBY et al. 1983 a, 1983 b, 1984). Gasol treatment tended to decrease plasma urea $\mathrm{N}$ content. Fish meal has been found to increase blood glucose concentration (KIRBY et al. $1983 \mathrm{~b}, 1984)$, but in the present study no effect due to RSM supplement was noted.
In conclusion. the present study indicates that RSM can be used as protein supplement on silage diets. RSM supplement increased liveweight gain in growing cattle, which may be the result partly of increased amino acid supply and partly of increased energy intake. RSM increased significantly the ration digestibility. A further experiment is needed to evaluate the effect of RSM on silage diets in animals weighing up to $500 \mathrm{~kg}$.

\section{References}

Alaviuhiola, T. \& Nası, M. 1984. Gasol-treated barley for pigs. To be published.

ANON. 1980. The nutrient requirements of ruminant livestock. Commonwealth Agricultural Bureaux. 351 p.

Armstrong, D.G. 1980. Net efficiencies of microbial N synthesis in ruminant livestock. EAAP-publ. 27 (vol II): $400-411$.

BAX, J.A. \& OfFER, N.W. 1982. Measurement of rumen outflow rates and the effect of fish meal on digestibility in young Friesian calves. Anim. Prod. 34: 382. (Abstr.).

Beever, D.E., Thomas, D.J., Cammel, S.B. \& HarriSON, D.G. 1977. The digestion by sheep of silages made with and without formaldehyde. J. agric. Sci. (Camb.) 88: 61-70.

Davis, H.L. \& FaICHNEY, G.J. 1973. The effect of formaldehyde treatment of barley on productive performance of Friesian steers. Aust. J. Exp. Agric. Anim. Husb. 13: 142-145.

Edwards, I.E., Topps, J.H. \& Paterson, G.F.M. 1984.
Urea supplementation of two forms of barley for intensively fed Friesian bulls. Anim. Prod. 38: 551 (Abstr.).

Garstang, J.R., Thomas, C. \& Gill, M. 1979. The effect of supplementation of grass silage with fish meal on intake and performance by British Friesian calves. Anim. Prod. 28: 423 (Abstr.).

Gill, M. \& England, P. 1984. Effect of degradability of protein supplements on voluntary intake and nitrogen retention in young cattle fed grass silage. Anim. Prod. 39: 31-36.

- \& England, P. 1983. The effect of fish meal and sucrose supplements on voluntary intake of silage and liveweight gain in young cattle. Anim. Prod. 36: 513 (Abstr).

Huhtanen, P. 1984 a. Wood molasses as a preservative for high moisture barley. 1. Preservation and digestibility in pig. J. Agric. Sci. Finl. 56: 255-263.

- 1984 b. III. feeding value for growing cattle. J. Agric. Sci. Finl. 56: 275-282. 
HuIDA, L. 1979. Haihtuvien rasvahappojen kvantitatiivinen mäărittăminen pötsinesteestă ja săilörehusta kaasukromatografisesti. J. Scient. Agric. Soc. Finl. 45: $485-488$.

KAY, M. \& Scotr, L. 1984. Fish meal supplementation of grass silage diets for growing stock. Anim. Prod. 38: 551. (Abstr.).

— \& KING, M.E. 1982. Nitrogen supplementation of grass silage diets for growing stock. Anim. Prod. 34: 388. (Abstr.).

Kaufmann, W. \& LÖPING, W. 1982. Protected proteins and protected amino acids for ruminants. Protein contribution for ruminants. Ed. Miller, E.L., Pike. I.H. \& van Es, A.J.H. p. 36-75. Butterworths.

Kirby, P.S., Outwaite, J.R. \& Jones, T.O. 1984. A comparison of two types of fish meal as protein supplements for finishing British Friesian steers given grass silage ad libitum. Anim. Prod. 38: 551 (Abstr.).

-, Chalmers, A.J. \& Hannam, D.A.R. 1983 a. Fish meal supplementation of grass silage diets for fattening British Friesian steers. Anim. Prod. 36: 538 (Abstr.).

-, Chalmers, A.J. \& Clark, W.A. 1983 b. A comparison of formaldehyde-treated soya bean meal and two types of fish meal as protein supplements for growing beef cattle given grass silage ad libitum. Anim. Prod. 36: 538 (Abstr.).

- \& Chalmers, A.J. 1982. A comparison of extracted soya bean meal and fish meal as protein supplements for growing beef cattle given grass silage ad libitum. Anim. Prod. 34: 386 (Abstr.).

LindBerG, J.E. 1984. Rumen fermentation and digestibility on a grass silage diet unsupplemented or supplemented with soyabean meal. Paper presented in Kielgroup meeting. 13-15. 11. 1984. Kiel.

— \& Otsson, I. 1983. Live weight gain in intensively reared bulls fed ration with low and high degradable protein. IVth Int. Symp. Protein Metabolism and Nutrition. p. 243-246.

McGullough, H. 1967. The determination of ammonia in whole blood by a direct colorimetric method. Clin. Chem. Acta. 17: 297-304.

OLsson, I. 1978. Rapeseed meal as a protein supplement for growing bulls. Proc. Vth Int. Rapeseed. Conf. Vol. 2: 230-234.

Ørskov, E.R. \& McLeod, N.A. 1982. The determination of minimal nitrogen excretion in steers and dairy cows and its physiological and practical implications. Br. J. Nutr. 47: 625-636.

Petry, H \& RaPp, W. 1971. Chromoxidbestimmung in Verdauungsversuchen. Z. Tierphys. Tierern. u. Futtermittelkde. 27: 181-189.

SAlo, M-L. \& SAlmi, M. 1968. Determination of starch by amyloglucosidase method. J. Scient. Agric. Soc. Finl. 40: 38-45.
-, TUORI, M \& KiISKinen, T. 1982. Rehutaulukot ja ruokintanormit. 70 p. Helsinki.

SATter, L.D. \& Roffler, R.E. 1975. Nitrogen requirements in dairy cattle. J. Dairy Sci. 58: 1219-1237.

SetÃLĀ, J. 1983 a. Lypsylehmien valkuaisen tarve ja sen ruokinnalle asettamat vaatimukset (Protein requirements and protein feeding of dairy cows). Työtehoseuran julkaisuja 252: $1-60$.

- $1983 \mathrm{~b}$. The nylon bag technique in the determination of ruminal feed protein degradation. J. Scient. agric. Soc. Finl. 55: 1-78.

-, Syrjālā-Qvist, L., Poutiainen, E., Tuori, M. \& RIIPINEN, U. 1984. Feeding high production dairy cows according to rumen undegradable protein requirements in grass silage based diet. J. Agric. Sci. Finl. 56: $73-82$.

Steel, R.G. \& Torrie, J.H. 1960. Principles and procedures of statistics. New York. 481 p.

Thomas, C., Gill, M. \& Austin, A.R. 1980. The effect of supplements of fish meal and lactic acid on voluntary intake of silage by calves. J. Br. Grassl. Soc. 35: 275-279.

ThомAs, P.C. 1982. Utilization of conserved forages. Forage protein in ruminant animal production. Ed. Thomson, D.J., Beever, D.E. \& Gunn, R.G. p. 67-76. British Society of Animal Production.

Thomas, P.C. \& Chamberlain, D.G. 1982. Silage as a foodstuff. Silage for milk production. Ed. Rook, J.A.F. \& Thomas,.P.C. p. 63-101. Technical Bulletin 2. National Institute for Research in Dairying, Hannah Research Institute.

-, Chamberlain, D.G., Kelly, N.C. \& Wait, M.K. 1980. The nutritive value of silages. Digestion of nitrogenous constituents in sheep receiving diets of grass silage and barley. Br. J. Nutr. 43: 469-479.

Thomson, D.J., Beever, D.E., Lonsdale, C.R., Halnes, M.J., Cammel, S.B. \& Austin, A.R. 1981. The digestion by cattle of grass silage made with formic acid and formic acid-formaldehyde. Br. J. Nutr. 46: 193-207.

Thornton, J.H., Owens, F.N., Willams, D.E. \& Arnold, M. 1977. Fermentation and digestion of formaldehyde treated ensiled high moisture corn grain. Okla. Agr. Exp. Sta. MP-101: 62-67.

Verite, R., Journet, M. \& Jarrige, R. 1979. A new system for protein feeding of ruminants: PDI system. Livest. Prod. Sci. 6: 349-367.

Waterhouse, A., Laird, R. \& Holliday, R.J. 1983. A response to protein supplementation of grass silage for growing and finishing cattle. Anim. Prod. 36: 503 (Abstr.).

Ms received February 15, 1985 


\section{SELOSTUS}

\section{Rypsirouhe ja Gasol-käsitelty ohra lihanaudoilla vapaalla säilörehuruokinnalla}

\author{
Pekka Huhtanen, Esko Poutiainen ${ }^{1}$ ja \\ Timo Mikkola ${ }^{2}$ \\ Helsingin yliopisto, kotieläintieteen laitos, \\ 00710 Helsinki 71
}

Rypsirouheen ja ohran suojauskäsittelyn vaikutusta vapaalla säilörehuruokinnalla tutkittiin 16 Ay-vasikalla 196 påivăă kestăneessă ruokintakokeessa. Koe tehtiin $2 \times 2$ faktorikokeena, jossa faktoreina olivat viljan kăsittely ja valkuaistäydennys. Ohran säilöntäaineena käytettiin joko $0.85 \%$ propionihappoa (P) tai $1.28 \%$ Gasol-liuosta (G). Ohra-annos oli $45 \mathrm{~g}$ kuiva-ainetta/kg $W^{0.75}$. Puolet sekă P-ettă G-ryhmän elăimistă sai valkuaistăydennyksenä rypsirouhetta (R) UDP-tarpeen (pötsissä hajoamaton rehuvalkuainen) mukaan, puolet ei saanut valkuaistäydennystä $(0)$. Koe-eläinten keskimăäräinen elopaino kokeen alussa oli $106 \mathrm{~kg}$ ja ikă 86 pv.

Lisăkasvu oli 1066 ja $1070 \mathrm{~g} / \mathrm{pv}$ ja P- ja G-ryhmällă sekă 1012 ja 1124 g/pv $(\mathrm{P}<0.01) 0$ - ja R-ryhmăllă. Vastaavat rehunkulutukset kasvukiloa kohti olivat 3.77, $3.64,3.75$ ja 3.66 ry. Rehun syöntiin rypsirouheella ei ollut vaikutusta. Rypsirouhe paransi merkitsevästi $(\mathrm{P}<0.05)$ orgaanisen eineen, raakavalkuaisen ja raakakuidun sulavuutta. Sulavuudet olivat R-ruokinnalla $73.5,67.4$ ja $60.2 \%$ sekä 0-ruokinnalla $71.1,62.8$ ja $57.2 \%$.
Laadultaan säilötyt viljat olivat hyviä. Gasolilla săilötyssä ohrassa vesiliukoisen typen osuus oli alempi ja nailonpussimenetelmällă määritetty raakavalkuaishävikki oli 9 tunnissa $46.6 \%$ vastaavan hävikin ollessa Pohralla $76.4 \%$. Samoin Gasol-kăsittely văhensi kuivaaineen ja tärkkelyksen hajoamisnopeutta pötsissă. Imeytyneiden aminohappojen hyväksikäyttö oli faktoriaalisti laskettuna eri ruokinnoillı $0.566 \pm 0.010$.

Plasman ureapitoisuus oli R-ruokinnalla korkeampi $(\mathrm{P}<0.05)$ kuin 0-ruokinnalla. Etikkahapon osuus pötsinesteen VFA:sta oli R-ryhmällă alempi $(\mathrm{P}<0.05)$ ja propionihapon korkeampi $(\mathrm{P}<0.01)$ kuin 0 -ryhmällă. G-ohralla propionihapon osuus VFA:sta oli alempi $(\mathrm{P}<0.05)$ kuin G-ohralla.

\footnotetext{
1 Nykyinen osoite:

Maatalouden tutkimuskeskus

31600 Jokioinen

2 Farmos-Yhtymä Oy

Tengströminkatu 6

20360 Turku
} 